\title{
MORTALITY OF DIPETALOGASTER MAXIMUS (UHLER) IN RESPONSE TO TEMPERATURE AND HUMIDITY
}

\author{
Colin E. Johnson ${ }^{1}$, Elaine F. Oakley ${ }^{1}$ and Philip D. Marsden ${ }^{2}$
}

\begin{abstract}
Observations were made on the mortality of Dipetalogaster maximus in relation to humidity and temperature in controlled conditions. The bugs survived longer at higher relative humidities and at lower temperatures, but when these results were plotted against vapour pressure deficit, no independent temperature effect was seen. The results may be explained by the faster depletion of water reserves at higher vapour pressure deficits. $\mathrm{D}$. maximus did not increase its resistance to water vapour transfer at higher vapour pressure deficits. In order to increase survival rates when D. maximus is used for xenodiagnosis in field conditions it should be protected against high temperatures and low humidities.
\end{abstract}

Key words: Dipetalogaster maximus. Mortality. Humidity. Temperature.

Xenodiagnosis of Chagas' disease has been routinely accomplished by using first instar nymphs of the bug Dipetalogaster maximus (Uhler) (Triatominae) 1347 . While this species is a more effective agent for xenodiagnosis than the previously used Triatoma infestans ${ }^{4}$, higher mortality was noted in $D$. maximus, and it was suggested ${ }^{7}$ that variations of temperature and humidity were involved.

Although under laboratory colony conditions unfed first instar D. maximus can survive for up to 120 days $^{2}$, little information is available on the survival of these bugs in different conditions of temperature and humidity.

The objective of this study was to improve survival rates of bugs used in field conditions for diagnosis of Chagas' disease by studying the mortality of eggs and first instar D. maximus in controlled temperatures and humidities.

\section{MATERIAL AND METHODS}

Eggs of D. maximus were collected during a period of one week from a laboratory colony maintained at the Núcleo de Medicina Tropical, University of Brasilia. The oviposition date was approximated by the mean date $(20.10 .79)$. The batch was separated into groups of 15-20 eggs and each group placed in a

1. Laboratório de Ecologia, Depto de Biologia Vegetal, Universidade de Brasilia.

2. Núcleo de Medicina Tropical e Nutrição, Universidade de Brasilia.

Recebido para publicação em 28/11/83. separate glass beaker with a muslin cover. The groups were equally distributed between the controlled humidity and temperature environments.

Commercially available incubators (Griffin \& George Ltd., London) were used to control the temperature between ambient $\left(25^{\circ} \mathrm{C}\right)$ and $34^{\circ} \mathrm{C}$. In this equipment, air heated by a thermostatically controlled light bulb is allowed to circulate through the chamber. Humidity was controlled separately in a series of $30 \mathrm{~cm}$ desiccators, using glycerol solutions of different concentrations ${ }^{11}$. A small quantity of copper sulphate was added to the solutions to avoid the growth of mould. The humidity treatments were maintained at room temperature. The glycerol solutions permitted a range of between 30 and $100 \%$ relative humidity $(\mathrm{RH})$, and dry silica gel was used to provide a $\mathrm{RH}$ of $20 \%$. All the experiments were done in a small insulated room where the temperature measured by a thermograph varied between 23 and $26^{\circ} \mathrm{C}$ during test period (March-June 1980).

The humidities were measured using a fine wire copper-constantan thermocouple psychrometer and a millivoltmeter ${ }^{11}$, and did not vary significantly during the experiment. Vapour pressure deficits (VPD) (i.e. the difference in water vapour pressure between the evaporating surface and the environment) were calculated assuming that the air in contact with the wet surface is saturated with water vapour. Thus VPD = $e_{s}(T)-e_{a}$ where $e_{s}(T)$ is the saturated vapour pressure at the temperature $T$, and $e_{a}$ the ambient vapour pressure. The bug temperatures were assumed equal to the ambient. Conversion from relative humidity to VPD may be made using the formula:

$$
\mathrm{VPD}=\mathrm{e}_{\mathrm{S}}(\mathrm{T}) \cdot(1-\mathrm{RH} / 100)
$$


Johnson CE, Oakley EF, Marsden PD. Mortality of Dipetalogaster maximus (Uhler) in response to temperature and humidity. Revista da Sociedade Brasileira de Medicina Tropical 17: 17-20, Jan-Mar, 1984

While the temperature of the humidity series was maintained constant, it was not possible to keep the VPD constant in the controlled temperature chambers. Table 1 shows the temperature and humidity series used.

At about five day intervals, the groups of eggs or bugs were checked to determine mortality rates, and each batch was weighed. The lethal time to $50 \%$ mortality (LT 50) of the hatched bugs was measured for each treatment.

\section{RESULTS}

\section{Eggs}

The percentage mortality rates of $D$. maximus in the egg stage in various conditions of temperature and humidity are shown in Table 1 . It is not possible to demonstrate any effect of temperature beyond that of increasing the VPD. The mortality of eggs held in conditions of VPD greater than $2.0 \mathrm{kPa}$ was significantly higher than those in lower VPD (chi-squared, $\mathbf{p}<1 \%$ ).

Table 1 - Mortality rates in the egg stage of $\mathrm{D}$. maximus held in various conditions of temperature and humidity. The corresponding vapour pressure deficits are also shown (VPD).

\begin{tabular}{|c|c|c|c|c|c|c|c|c|c|c|}
\hline & \multicolumn{5}{|c|}{ Relative Humidity (\%) } & \multicolumn{5}{|c|}{ Temperature $\left({ }^{\circ} \mathrm{C}\right)$} \\
\hline & 20 & 32 & 62 & 74 & 100 & 25 & 28 & 30 & 32 & 34 \\
\hline$V P D(k P a)$ & 2.7 & 2.3 & 1.3 & 0.9 & 0 & 0.8 & 1.4 & 1.9 & 2.4 & 3.1 \\
\hline Egg Mortality (\%) & 40 & 5 & 15 & 10 & 15 & 15 & 10 & 10 & 25 & 50 \\
\hline
\end{tabular}

\section{First instar bugs}

After hatching, the mortality rate was low or zero until an initial point was reached when it increased rapidly. The time taken to reach this point varied from about 80 days after oviposition at a VPD of $0.8 \mathrm{kPa}$ to about 30 days at $3.0 \mathrm{kPa}$, and no significant diference between the humidity and temperature controls was found.

The mortality (LT 50) was proportional to the VPD, as shown in Fig. 1. Linear regression analysis showed that $95 \%$ of the variance could be explained by this factor, and there was no significant difference between the temperature and humidity controls. The unusually high mortality observed at zero VPD $(100 \%$ RH) was excluded from the analysis, and was probably due to a pathogenic fungus.

The rate of weight loss of the first instar bugs was virtually constant for each treatment, and linear regression analysis was used to calculate the mean rate of weight loss. As expected, the mortality rates can be related with this rate (Fig. 2). The rate of weight loss at $34^{\circ} \mathrm{C}$ was much greater than at other temperatures.

Short $(<1 \mathrm{~h})$ exposure times at temperatures above $45^{\circ} \mathrm{C}$ are lethal to this species. First instar $D$. maximus exposed to bright sunshine (total solar radiation $=1000 \mathrm{~W}^{\prime} \mathrm{m}^{-2}$ ) and sheltered from the wind in a glass beaker were found to die after only six minutes, presumably from temperature effects.

\section{DISCUSSION}

The high correlation between mortality rates and vapour pressure deficit in unfed bugs is probably due to the depletion of water reserves. The rate of water vapour diffusion is expected to be proportional to the vapour pressure deficit ${ }^{69}$, and providing that the resistance to water vapour transfer remains constant, bugs will survive longer in more humid environments.

Many insects can increase their resistance when exposed to higher vapour pressure deficits ${ }^{6}$, but this effect was not observed with $D$. maximus where resistance had a tendancy to decrease with vapour pressure deficit. The constant rate of weight loss observed in each treatment showed that the resistance to water loss was constant during the experiment. At $34{ }^{\circ} \mathrm{C}$ water loss was 2-3 times that at other temperatures, sugesting decreased cuticular resistance or increased spiracular opening.

To ensure high survival rates when used in xenodiagnosis, the bugs should be protected against high temperatures and low humiditics. This may be done by using a closed polystyrene foam container with a damp cloth to maintain humidity. Barreto et $\mathrm{al}^{2}$ recommended a temperature of $22-27^{\circ} \mathrm{C}$ for maximal 
Johnson CE, Oakley EF, Marsden PD. Mortality of Dipetalogaster maximus (Uhler) in response to temperature and humidity. Revista da Sociedade Brasileira de Medicina Tropical 17: 17-20, Jan-Mar, 1984

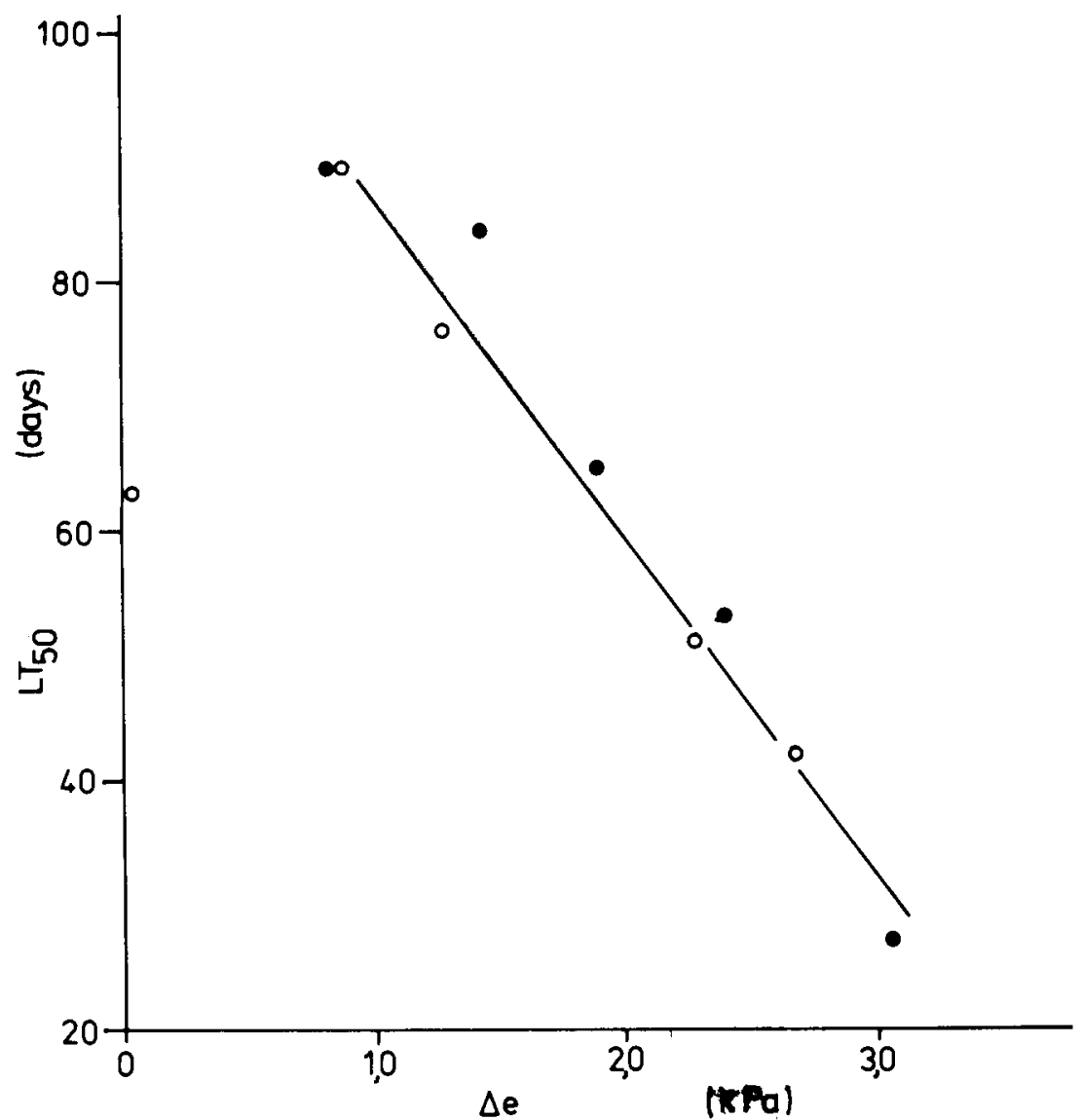

Fig. 1 - The relationship between mortality rate (LT 50) of D. maximus and the vapour pressure deficit (VPD). The linear regression line is shown. Temperature controlled (o), humidity controlled (o).

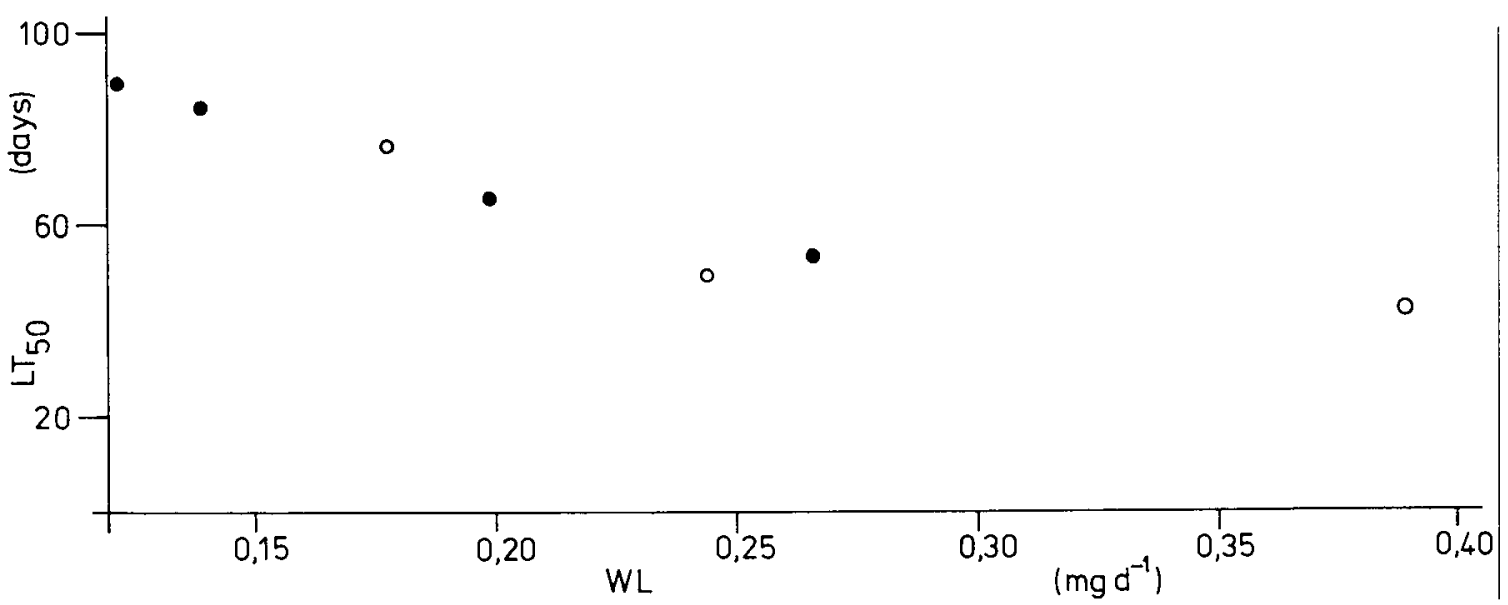

Fig. 2 - The relationship between mortality rate (LT 50) of D. maximus and the mean rate of weight loss per insect in each group (WL). Two data points were not included: for $100 \% \mathrm{RH}$ and $34^{\circ} \mathrm{C}$ (see text). Temperature controlled (o), humidity controlled (o). 
Johnson CE, Oakley EF, Marsden PD. Mortality of Dipetalogaster maximus (Uhler) in response to temperature and humidity. Revista da Sociedade Brasileira de Medicina Tropical 17: 17-20, Jan-Mar, 1984

egg production from $D$. maximus in colonies. Triatoma infestans has been shown to prefer a temperature of areund $27^{\circ} \mathrm{C}^{5}$. Very high humidities may stimulate pathogenic fungal attack.

Two studies ${ }^{810}$ made in the natural habitat of D. maximus show that the bugs are attracted to potential hosts in the open even in conditions of bright sunshine when the rocks are hot to touch and may approach the lethal temperature. Even though these conditions appear unfavourable, they do not prevent the bugs from searching for food, and the short survival times of unfed bugs may explain this behaviour.

\section{SUMÁRIO}

Observou-se a mortalidade do Dipetalogaster maximus em relação à temperatura e umidade, em condiçoes controladas. Os triatomineos sobreviveram maior tempo em umidades relativas mais altase em temperaturas mais baixas, mas quando estes resultados foram distribuidos graficamente em condições de baixa pressão, nenhum efeito foi visto, independentemente da variacão de temperatura. $O$ resultado pode ser explicado pela evaporação mais rápida de água nas condições de baixa pressão. $O \mathrm{D}$. maximus não aumenta sua resitência quando se injeta vapor de água em ambientes de baixa pressão. Para aumentar a sobrevida do D. maximus quando usado para xenodiagnóstico em condicões de campo é conveniente protegê-lo das altas temperaturas $e$ baixas umidades.

Palavras-chaves: Dipetalogaster maximus. Mortalidade. Umidade. Temperatura.

\section{ACKNOWLEDGEMENTS}

The authors would like to thank Prof. Aluizio Prata for providing the experimental material. Dr. Barry Moser analysed some of the data and Dr. C. J. Schofield helped in the preliminary experiments. The equipment used in the study was bought using research funds provided by FINEP and The British Council. We would like to thank Dr. A. Bosworth for making constructive cristicisms to an earlier manuscript.

\section{REFERENCES}

1. Barreto AC, Marsden PD, Cuba CC, Alvarenga NJ. Estudo preliminar sobre o emprego de Dipetalogaster maximus (Uhler, 1894) (Triatominae) na técnica do xenodiagnóstico em forma crônica da doença de Chagas. Revista do Instituto de Medicina Tropical de São Paulo 20: 183-189, 1978.

2. Barreto AC, Prata AR, Marsden PD, Cuba CC, Trigueira CP. Aspectos biológicos e criação em massa de Dipetalogaster maximus (Uhler, 1894) (Triatominae). Revista do Instituto de Medicina Tropical de São Paulo 23: 18-27, 1981.

3. Cuba CC, Alvarenga NJ, Barreto AC, Marsden PD, Chiarini C. Nuevos estudios comparativos entre Dipetalogaster maximus y Triatoma infestans en xenodiagnóstico de la infección chagásica crónica humana. Revista do Instituto de Medicina Tropical de Sảo Paulo 20: 145-151, 1978.

4. Cuba CC, Alvarenga NJ, Barreto AC, Marsden PD, Macedo V, Gama MP. Dipetalogaster maximus (Hemiptera, Triatominae) for xenodiagnosis of patients with serologically detectable Trypanosoma cruzi infection. Transactions of the Royal Society of Tropical Medicine and Hygiene 73: 524-527, 1979.

5. Di Luciano VS. Orientation of Triatoma infestans (Hemiptera: Reduviidae) to environmental temperatures. Journal of Medical Entomology 20: 446-454, 1983.

6. Edney EB. Water balance in land arthropods. SpringerVerlag, Berlin, p. 282, 1977.

7. Marsden PD, Barreto AC, Cuba CC, Gama MD, Ackers J. Improvements in routine xenodiagnosis with first instar Dipetalogaster maximus (Uhler, 1894) (Triatominae). The American Journal of Tropical Medicine and Hygiene 28: 649-652, 1979.

8. Marsden PD, Cuba CC, Alvarenga NJ, Barreto AC. Report on a field collection of Dipetalogaster maximus (Hemiptera. Triatominae) (Uhler, 1894). Revista do Instituto de Medicina Tropical de São Paulo 21: 202206, 1979.

9. Monteith JL, Campbell GS. Diffusion of water vapour through integuments - potential confusion. Journal of Thermal Biology 5: 7-9, 1980.

10. Ryckman RE, Ryckman AE. Epizootiology of Trypanosoma cruzi in southwestern North America. Part X: The biosystematics of Dipetaiogaster maximus in Mexico (Hemiptera: Reduviidae) (Kinetoplastida: Trypanosomidae). Journal of Medical Entomology 4: 180-188, 1967.

11. Slavik B. Methods of studying plant water relations. Ecological studies vol. 9. Springer-Verlag, Berlin, p. $449,1974$. 